Mariusz Bartosiak

Tomasz Ciesielski

\title{
WPROWADZENIE DYNAMIKA STRATEGII CHOREOGRAFICZNYCH A ZASADA SAMOREGULACJI ODŚRODKOWEJ
}

Współcześnie znaczenia i funkcje choreografii niezwykle się rozszerzają - i to nie tylko w ramach praktyki artystycznej, nawet tej wychodzącej poza taniec (choreographing space, choreographing problems, choreographing empathy itp.). Choreografia to także termin pozwalający adekwatnie opisywać zdarzenia kulturowe (ethical choreography, choreography of communication, choreography of consciousness, choreography of multiculture itp.), a nawet zjawiska naturalne (np. choreography of bacteria). Kulturowe, społeczne i polityczne konsekwencje tych metafor są dziś szeroko eksplorowane i dyskutowane, w przestrzeni praktyk zarówno artystycznych, jak i badawczych.

Jednak szczegółowe kwestie związane z zastosowaniem różnorodnych strategii twórczych czy procedur metodologicznych dopiero od niedawna stają się przedmiotem wnikliwych analiz. Możliwą przyczyną tego stanu rzeczy jest brak odpowiedniego aparatu pojęciowo-wyobrażeniowego, który byłby wystarczająco skuteczny w ich opisywaniu. Jedną z odpowiedzi na ten problem jest coraz częstsze odwoływanie się do choreografii lub tańca jako metafory poznawczej służącej opisywaniu kolejnych zjawisk. Zastępuje ona wciąż w wielu obszarach aktualne metafory mające u podstawy m.in. organizm, komputer lub teatr. Nie oznacza to automatycznie, że w perspektywie współczesnych badań jest ona od nich w jakiś sposób bardziej funkcjonalna, bez wątpienia jednak odkrywa takie aspekty wybranych fenomenów, których nie ujawniały inne.

Zebrane w tej publikacji artykuły odsłaniają kilka możliwych obszarów, w których choreografia okazuje się adekwatnym językiem opisu, strategią działania, matrycą poznawczą lub metodą badawczą. Są także dla siebie nawzajem nielinearnym, sieciowym wprowadzeniem - kładą fundament pod nasze współczesne rozumienie choreografii, a także swego rodzaju choreograficzne myślenie, służące zaistnieniu jej w kolejnych kontekstach. Relacje między różnymi ujęciami nie są oczywiste i mogą wydawać się przypadkowe. Kluczowe jest tutaj przyjęcie odpowiednio szerokiej perspektywy, w ramach której obowiązywałaby jednak pewna zasada nadająca jej nie tylko wewnętrzną spójność, ale również przybliża- 
łaby złożoną, wieloaspektową dynamikę szeroko rozumianych strategii choreograficznych.

Proponujemy ujęcie, w którym nadrzędna jest zasada samoregulacji odśrodkowej. Jedną z jej pierwszych wersji sformułował w XIX wieku Alfred Russel Wallace, jeden z twórców ewolucjonizmu biologicznego (Brooks 1984, Brackman 1980), jako podstawową zasadę selekcji naturalnej. Bezpośrednią inspiracją był dla niego mechanizm wynalezionego wiek wcześniej niewielkiego urządzenia, które pozwalało zapanować nad dość nieprzewidywalną dynamiką napędu parowego i bez którego $\mathrm{w}$ efekcie rewolucja przemysłowa w znanej nam postaci nie miałaby szansy zaistnieć. W przeciwieństwie do urządzenia rządząca nim zasada nie zyskała popularności. Dla jego użytkowników liczyła się skuteczność i umiejętność złożenia prostego w istocie mechanizmu, natomiast dla naukowców (nie tylko dla humanistów) sama zasada była chyba zbyt skomplikowana - szukali wtedy raczej bezpośrednich związków przyczynowo-skutkowych, które układałyby się w liniowe, przewidywalne sekwencje. Dopiero XX wiek, a szczególnie jego druga połowa, skierował uwagę przedstawicieli właściwie wszystkich dyscyplin naukowych na zjawiska i procesy, które sprawiają wrażenie chaotycznych i nieprzewidywalnych. Od niedawna zaczynamy zdawać sobie sprawę, że proste schematy przyczynowo-skutkowe nie sprawdzają się w opisywaniu coraz bardziej złożonej rzeczywistości. Jednocześnie rozwój nauki zaowocował narzędziami badawczymi, przede wszystkim intelektualnymi, które dają nam pełniejszy obraz teraźniejszości, ale również pozwalają na głębsze rozumienie przeszłości i jej coraz mniej oczywistych związków ze współczesnością. Jednym z takich narzędzi intelektualnych, zdobywających coraz większą interdyscyplinarną popularność, staje się właśnie zasada samoregulacji odśrodkowej. Zanim jednak przyjrzymy się samej zasadzie i jej zastosowaniom poznawczym, warto poświęcić chwilę uwagi wspomnianemu wyżej niewielkiemu, ale bardzo efektywnemu urządzeniu mechanicznemu.

\section{Regulator odśrodkowy obrotów}

Wynalezienie i później rozszerzanie zastosowań silnika parowego pod koniec XVIII wieku stało się istotnym stymulatorem rozwoju przemysłowego. Wymusiło to na inżynierach znalezienie sposobu efektywnego kontrolowania mocy silnika w taki sposób, by uzyskać niezbędną do pracy stałą prędkość obrotów. James Watt zaproponował rozwiązanie stosowane wcześniej w mechanizmach wiatrakowych - odśrodkowy regulator obrotów (ang. centrifugal governor). Składał się on $\mathrm{z}$ pionowego trzpienia połączonego z głównym kołem zamachowym przekładnią $\mathrm{w}$ ten sposób, że obracał się on $\mathrm{z}$ prędkością zależną bezpośrednio od prędkości samego koła zamachowego. Do trzpienia zawiasami przymocowane były dwa ramiona, a na końcu każdego z nich znajdowała się metalowa kulka. 
Gdy trzpień się obracał, siła odśrodkowa powodowała, że kulki były wyrzucane na zewnątrz, a tym samym do góry. Ten ruch ramienia był połączony prostą przekładnią bezpośrednio z zaworem regulującym dopływ pary do systemu. W rezultacie wraz ze wzrostem prędkości koła głównego następowało podniesienie się ramion, przymknięcie zaworu i ograniczenie przepływu pary. Gdy prędkość zmniejszała się, ramiona z kulkami opadały pod wpływem siły grawitacji, a zawór otwierał się i umożliwiał przepływ większej ilości pary. Dzięki temu rozwiązaniu silnik utrzymywał stałą i stabilną prędkość w obecności dużych wahań ciśnienia i obciążenia. Rozwiązanie było genialne w swojej prostocie.

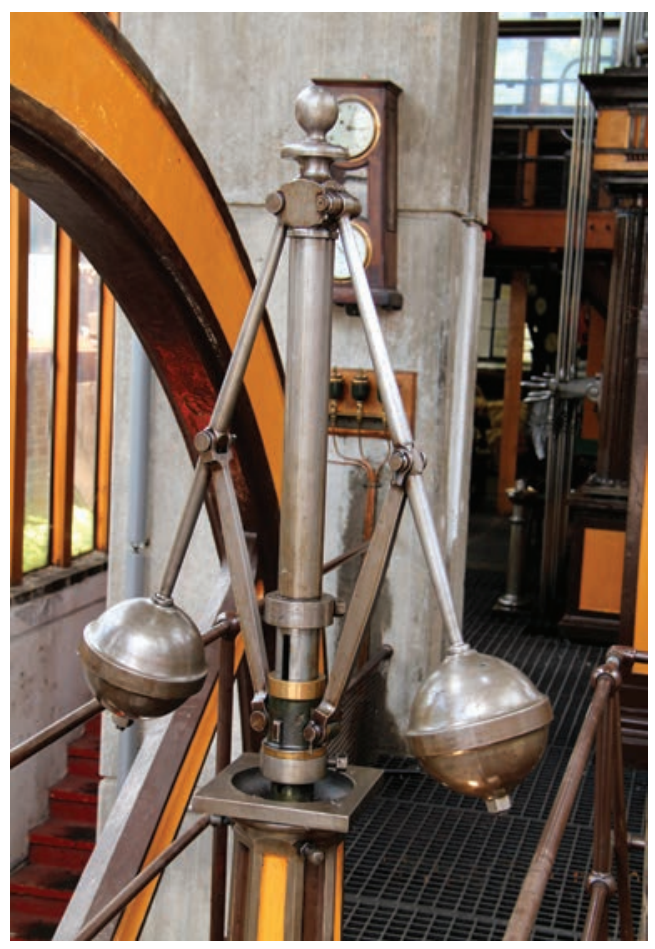

Zdj. 1. Odśrodkowy regulator obrotów zastosowany w silniku parowym

Źródło: https://pl.depositphotos.com/search/governor-steam-engine.html?quiew $=155271310$

Urządzenie to $\mathrm{w}$ elegancki sposób rozwiązywało niezwykle ważki w tamtych czasach problem osiągnięcia swoistej homeostazy w działaniu urządzeń napędzanych silnikiem parowym epoki rewolucji przemysłowej. Użycie terminu kojarzonego raczej z procesami biologicznymi nie jest tu przypadkowe. Wyjątkowość rozwiązania Watta spostrzegł w 1858 r. Wallace, opisując mechanizm naturalnej selekcji w przyrodzie: 
Działanie tej zasady [doboru naturalnego] jest w istocie takie samo jak w przypadku odśrodkowego regulatora silnika parowego, który sprawdza i koryguje wszelkie nieprawidłowości tuż przed tym, gdy staną się widoczne. I w podobny sposób brak równowagi w królestwie zwierząt nie może osiągnąć żadnej znacznej wielkości, ponieważ od początku staje się odczuwalny, sprawiając, że egzystencja jest utrudniona i prawie na pewno zagrożona wyginięciem (Wallace 1970, s. 97).

W pracy Steps to an Ecology of the Mind z 1972 r. antropolog Gregory Bateson tak skomentował ten fragment:

Silnik parowy z regulatorem jest po prostu cyrkulacyjnym ciągiem zdarzeń przyczynowych, posiadającym gdzieś w tym łańcuchu takie połączenie, że im więcej robi się czegoś, tym mniej następnej rzeczy w tym cyrkulacyjnym ciągu. Jeśli łańcuchom przyczynowym z tą ogólną charakterystyką dostarczyć energię, efektem będzie system samoregulacyjny. (...) W istocie, Wallace zaproponował pierwszy model cybernetyczny. (...) W zasadzie te systemy są zawsze konserwatywne (...). W takich systemach zmiany pojawiają się, aby zachować prawdę pewnej opisowej tezy, pewien składnik staus quo. Wallace ujrzał sprawę właściwie, bo selekcja naturalna działa głównie w celu utrzymania niezmienności gatunków (Bateson 1972, s. 435).

Tym samym użyta przez Wallace’a metafora była dla Batesona pierwszą teorią cybernetyczną, $w$ tym przypadku teorią ewolucji, zakładającą, że jest ona samoregulującym się systemem opartym na ujemnym sprzężeniu zwrotnym. Jak jednak zauważa Charles H. Smith (2004), wynikająca z tego konserwatywność systemu nie musi oznaczać, że nie dopuszcza on innowacji lub znacząco je spowalnia. W odniesieniu do maszyny parowej konserwatywność oznacza homeostazę skupioną wokół w miarę jednostajnej prędkości wyjściowej, innowacyjność natomiast oznacza zmianę tej prędkości. Oczywiście - gdy myślimy o jednej maszynie, która działa w stałych warunkach (co wydaje się całkiem naturalne $\mathrm{w}$ otoczeniu przemysłowym), każda, tym bardziej radykalna zmiana może prowadzić do awarii lub nawet katastrofy. Jednak odniesienie tej zasady do ewolucji wymusza korektę uwzględniającą niemal nieustannie zmieniające się warunki, co odpowiada dostosowaniu prędkości wyjściowej w maszynie parowej do urządzeń peryferyjnych, a te w XIX-wiecznych fabrykach zmieniały się relatywnie wolno. Czasem jednak warunki naturalne mogą się zmieniać bardzo szybko, a zasada nadal pozostanie funkcjonalna, ponieważ sama homeostaza jest względna.

Możliwe do pomyślenia społeczne i kulturowe aplikacje tej zasady są bardzo szerokie, ponieważ sama zasada obejmuje dynamiczną interakcję różnorodnych czynników, a także uwzględnia adaptację do warunków, w jakich ta interakcja zachodzi. A zatem zasada ta zapewnia względną homeostazę w dynamicznej sytuacji dwóch (a skoro mowa o narzędziu intelektualnym, to można rozważać także większą liczbę) zróżnicowanych sil, których interakcja przynosi w efekcie trzecią, 
niesprowadzalną do dwóch poprzednich jakość. Daje również możliwość adaptacji do zmiennych warunków środowiskowych. Jedną z istotnych cech tej zasady jest całkowicie nieintuicyjna różnorodność sił/czynników wchodzących w interakcję - nie muszą, a nawet nie powinny one mieć tej samej natury czy kierunków działania, mogą operować w zupełnie innych plaszczyznach (nie muszą być standardowo opozycyjne). Głównym warunkiem jest ich dynamiczna interakcja i całkowicie różny od nich efekt tej interakcji. Można w tym kontekście pomyśleć o aplikacji tej zasady do badania homeostatycznego trwania oraz ewolucyjnych i rewolucyjnych przemian wszelkiego typu konwencji kulturowych, jako efektów złożonej dynamiki społecznych sił o zróżnicowanej naturze i płaszczyznach oddziaływania.

Opartą na odśrodkowym kontrolerze obrotów refleksję Batesona w obszarze nauk humanistycznych rozwija i umieszcza w kontekście kognitywnych teorii poznania i badań nad sztuczną inteligencją Tim van Gelder (1995). Zwraca on uwagę, że system kontrolowany przez urządzenie Watta, a właściwie sam jego mechanizm, nie daje się efektywnie opisać za pomocą standardowych strategii języka matematycznego czy, mówiąc inaczej, w oparciu o mechanizm reprezentacji. Właśnie temu ma też zawdzięczać swoją efektywność. Rozwiązanie tego samego problemu w trybie obliczeniowym wymagałoby wielostopniowego algorytmu obejmującego:

1. Pomiar prędkości koła zamachowego.

2. Porównanie aktualnej prędkości z oczekiwaną.

3. W przypadku zgodności obu wartości powrót do kroku 1 . W innym przypadku:

a. pomiar ciśnienia pary,

b. obliczenie koniecznej korekty ciśnienia,

c. obliczenie niezbędnej korekty ustawienia zaworów.

4. Korektę ustawienia zaworów.

5. Powrót do kroku 1. (van Gelder 1995, s. 348).

Każde $\mathrm{z}$ tych zadań wymagałoby zastosowania odpowiednich urządzeń $\mathrm{i}$, potencjalnie, zwiększenia liczby koniecznych kalkulacji. Współcześnie relatywnie łatwo wyobrazić sobie skonstruowanie takiego sterowanego komputerowo urządzenia. Wciąż jednak byłoby ono prawdopodobnie bardziej narażone na usterki i zdecydowanie mniej eleganckie niż regulator odśrodkowy. Strategia obliczeniowa nie nadaje się także do opisu działania urządzenia Watta. Jak stwierdza van Gelder, jest tak, ponieważ nie opiera się ono na reprezentacji, która jest zbyt prosta, by uchwycić rzeczywistą relację pomiędzy regulatorem a silnikiem (van Gelder 1995, s. 353). Opisanie tej relacji wymaga stworzenia odpowiedniego modelu systemu dynamicznego, a więc biorącego pod uwagę czasowość działania mechanizmu. Nie tylko w zakresie czasu niezbędnego do przeprowadzenia pewnego procesu, ale szczegółów obejmujących rytm, czasy 
trwania i siły, jakie na nie wpływają. Dla australijskiego filozofa problem ten odzwierciedla różnicę pomiędzy matematycznymi a dynamicznymi, ucieleśnionymi modelami w naukach kognitywnych. Ponadto zdaniem van Geldera samo wprowadzenie tak rozumianego mechanizmu regulacyjnego pozwala w nowej perspektywie rozważać całą gamę podejmowanych w kognitywistyce problemów, przede wszystkim tych, które związane są ze ścisłą korelacją konkretnego zadania poznawczego (głównie podejmowania decyzji i poprzedzających je procesów przetwarzania różnego rodzaju danych) z bezpośrednim otoczeniem podmiotu.

Katalog zjawisk i procesów uwzględniających ścisłą wzajemną korelację heterogennych czynników, które przynoszą w rezultacie swojej samoregulującej się interakcji niesprowadzalne do nich efekty, znacznie rozszerza Leonard Mlodinow. Kluczowa jest dla niego nowa (w stosunku do psychologii Freuda czy Junga) koncepcja nieświadomości, bazująca na najnowszych badaniach aktywności mózgu. Świadomość, a także wszystkie tradycyjnie związane z nią procesy mentalne, jest nie tylko metaforycznym wierzchołkiem góry lodowej, ale wydaje się całkowicie zależna od danych i procesów nieświadomych:

(...) okazało się, że niektórych z nieświadomych procesów myślowych nigdy nie da się odkryć w wyniku prowadzonych w czasie psychoterapii rozważań nad sobą samym. Dotyczy to tych [procesów], które zachodzą w częściach mózgu niedostępnych dla umysłu świadomego (Mlodinow 2012, s. 26).

W oparciu o liczne badania stawia również mocniejszą tezę:

Nasze doświadczenia i wszystko, czego się podejmujemy, zawsze pozornie rodzą się ze świadomych myśli i trudno nam (...) zaakceptować fakt, że gdzieś w tle zachodzą niezależne procesy, które mimo że dla nas ukryte, wywierają potężny wplyw na wszystko, co robimy (Mlodinow 2012, s. 25).

Ten nowo odkryty i potwierdzony doświadczalnie typ nieświadomości, całkowicie burzący przekonanie o względnej niezależności i swego rodzaju równoległości świadomych i nieświadomych procesów, Mlodinow charakteryzuje w następujący sposób:

Postrzegamy, pamiętamy doświadczenia, wydajemy sądy, działamy i w każdej z chwil, w jakich to robimy, pozostajemy pod wplywem czynników, których istnienia nie jesteśmy świadomi. W rzeczywistości w nieświadomej części naszych umysłów działamy czynnie, bez skrępowania i niezależnie. Choć umysł nieświadomy jest przed nami ukryty, to efekty jego działania są jak najbardziej wyraźne, gdyż odgrywają one znaczącą rolę w kształtowaniu sposobu, w jaki świadoma część naszej osobowości zbiera doświadczenia i reaguje na świat (Mlodinow 2012, s. 46). 


\section{Strategie choreograficzne}

Obecna $\mathrm{w}$ historii nauk humanistycznych metafora mająca u podstawy odśrodkowy regulator obrotów Watta, bez względu na jej pozorną toporność, wydaje się funkcjonalna także dla dyskusji nad współczesnymi strategiami choreograficznymi. Zastosowana podobnie jak przez Wallace'a pozwala zobaczyć w choreografii system będący nie tyle trwałą strukturą, której efektem jest wykonany w rzeczywistości taniec, lecz dynamicznym układem regulującym homeostazę szeroko rozumianej sytuacji teatralnej. Jednak w przeciwieństwie do doboru naturalnego jego stan wyjściowy lub oczekiwany można w pewnym zakresie regulować. Konserwatywność systemu w kontekście sztuki można rozumieć jako konieczność utrzymywania transformacji form w tempie, które umożliwia korygowanie się całemu układowi. Warto wziąć również pod uwagę psychologiczny „efekt płynności”, polegający na bezpośrednim i nieco paradoksalnym wpływie formy informacji na odbiór jej treści: „Im mniej zrozumiała forma, tym treść wydaje się trudniejsza" (Mlodinow 2012, s. 35). Mlodinow twierdzi, że istotnym aspektem tego efektu jest „łatwość przyswajania informacji”, a więc przystępność formy „wywiera wpływ na ocenę tej informacji”, jednak ten wpływ pozostaje całkowicie poza naszą świadomością (Mlodinow 2012, s. 42). Tezy te mają oczywiście zastosowanie nie tylko do przekazu artystycznego.

Wytwarzanie nowych konwencji jest procesem, w którym uczestniczą zarówno twórcy, jak i odbiorcy. Biorąc pod uwagę procesy poznawczo-performatywne, które same w sobie tworzą systemy dynamiczne, zauważmy, że zasada samoregulacji odśrodkowej dotyczy również samego twórcy (i osobno zespołów twórczych), a także odbiorcy (oraz wspólnot odbiorczych). Warto podkreślić, że w każdym z tych systemów inne czynniki są regulowane tą samą zasadą. Wynika z tego, że funkcjonuje ona niezależnie na różnych hierarchicznie poziomach złożonych systemów dynamicznych (od wyodrębnianych w neurokognitywistyce procesów neuronowych i różnych modułów kognitywnych, poprzez akty poznawczo-performatywne pojedynczego podmiotu i zróżnicowane systemy społeczne, w których on uczestniczy, aż po historycznie i geograficznie warunkowane przemiany kulturowe i cywilizacyjne). Należy pamiętać, że na każdym z nich inne i wzajemnie różnorodne czynniki kształtują względną homeostazę.

Nie oznacza to jednak, że nie są możliwe radykalne innowacje. Mogą one pojawiać się $\mathrm{w}$ wyniku zmian otoczenia lub poprzez nawet nieznaczne przesunięcia strukturalne. Magoroh Maruyama opisuje możliwość zaistnienia w systemach dynamicznych pozytywnego sprzężenia zwrotnego, które zamiast redukować przemiany, wywołuje zmianę systemu w kierunku większej lub mniejszej entropii (Maruyama 1963). Tym samym proces choreograficzny może, $w$ trybie ekologicznej interakcji z otoczeniem, być bardzo dynamiczny. Należy przy tym 
pamiętać, że główne medium stanowi dla niego ciało lub, precyzyjniej, ucieleśnione poznanie:

Mam silne przekonanie co do tego, że ciało nie jest przedmiotem. Jest częścią całościowego środowiska w przestrzeni (...). Wierzę również filozoficznie, że ludzie nie są centrum wszechświata. Moje fizyczne ciało jest tym, do czego się odnoszę na pewnym poziomie, ale też to, co mnie najbardziej zastanawia, to powiązanie wychodzące poza, do otoczenia, i to jest moje ciało holistyczne (Interview with Anna Halprin, cyt. za: Cielątkowska 2013, s. 291-292).

Ludzkie poznanie (ang. cognition), w perspektywie, którą tutaj proponujemy, jest zatem istotą budowania strategii choreograficznych, których zastosowanie może wykraczać dalece poza formy sztuki. Podobne wnioski płyną z lektury tekstów zawartych w niniejszej publikacji.

\section{Korelacja heterogeniczna}

Logika wynikająca z opisanej zasady samoregulacji odśrodkowej pozwala na poszukiwanie praktyk artystycznych i badawczych, w których następuje dynamiczna korelacja nieprzystających do siebie porządków. Zarazem jej dostrzeżenie wymaga poszerzenia perspektywy poznawczej lub - w obszarze, któremu poświęcone są badania zawarte $\mathrm{w}$ tej publikacji - rekalibracji „pryzmatu choreograficznego" w taki sposób, by oświetlał większe pole badawcze. Takie przygotowanie stanowią otwierające tę monografię teksty Juliusza Grzybowskiego i Mariusza Bartosiaka, w których dokonują oni przeglądu toposów związanych $\mathrm{z}$ tańcem i choreografią $\mathrm{w}$ kulturze śródziemnomorskiej. W rozdziale pierwszym autor poprzez analizę inwariantów obrazów choreografii obecnych w mitologii greckiej wskazuje, jak dużej wrażliwości oraz wnikliwości wymaga prawidłowe rozpoznanie złożonej interakcji pomiędzy aspektem twórczym i petryfikującym (zapisującym) w choreografii, by rozciągnąć to postrzeganie na obecny w micie kontekst społeczny. W drugim rozdziale analiza tych samych toposów zostaje uporządkowana i znacznie rozszerzona, zarówno pod względem diachronicznym - kolejne aktualizacje wzorców, jak i synchronicznym - alternatywne ryty, także obecne w kulturze zachodniej. Zakończenie tekstu Mariusza Bartosiaka stanowi otwarcie tej głębokiej i zarazem szerokiej refleksji nad toposami tańca w kierunku współczesnych praktyk performatywnych. Z kolei Maxine Sheets-Johnstone, autorka następnego tekstu, odwołując się do myśli Arystotelesa, podejmuje krytykę „ucieleśnionych” (ang. embodied) paradygmatów w nauce i sztuce, według niej wtórnych i przysłaniających faktyczną dynamikę ruchu jako ludzkiego prymarnego sposobu doświadczania.

W dalszej części książki znajdują się rozdziały poświęcone konkretnym działaniom artystycznym, w których rozpoznawalne są strategie choreograficzne 
jako, nieco upraszczając, odpowiedniki regulatora odśrodkowego Watta. Umożliwiają one wspólistnienie w jednym zdarzeniu czynników pochodzących czasem z radykalnie różnych porządków. Sandra Frydrysiak opisuje rozmywanie się wyraźnych we współczesnych multimedialnych praktykach choreograficznych granic podmiotowości, której nośnikiem nie musi już być człowiek. Kwestię interpretacji instrukcji wykonawczej zapożyczonej przez medium eksploruje Pil Hansen, przywołując przy tym jako perspektywę opisową dynamiczne systemy generatywne. Problem włączenia do tańca przedmiotów nieożywionych porusza także, z innej perspektywy, Regina Lissowska-Postaremczak. Autorka przedstawia możliwe nienormatywne („pozaintelektualne”, „pozawzrokowe”, „pozaestetyczne”) formy doświadczania sztuki performatywnej, dekonstruując pozorny prymat wzrokowości w postrzeganiu tańca. Jeszcze bardziej radykalne stanowisko przyjmuje Esthir Lemi, która odwołując się za Nietzschem do terminu „naskórkowość (ang. epidermality), proponuje ponowne, szerokie włączenie w refleksję o współczesnym tańcu problematyki dotyku i powonienia - jako zmysłów wypartych przez współczesną kulturę Zachodu, ale „naskórnie” obecnych w doświadczaniu tańca. Odsłanianie efektów wyparcia tych „powierzchownych” zmysłów jest jednocześnie strategią ujawniania postępującej w naszej kulturze dehumanizacji sztuki.

Możliwość odkrywania ukrytych w ciele milczącej wiedzy i doświadczenia za pomocą strategii choreograficznych opisuje Katarzyna Pastuszak. W oparciu o wspomnienia z realizacji projektu Kantor_Tropy, zestawiającego w jednej praktyce artystycznej twórczość Tatsumiego Hijikaty i Tadeusza Kantora, analizuje ona relację pomiędzy tradycją i innowacją w sztuce, rozszerzając jednocześnie tę problematykę daleko poza obręb sztuki. W podobnym obszarze pamięci i doświadczenia wspólnotowego należy umieścić rozdział autorstwa Marty Keil. Autorka opisuje działania Any Vujanović, by rozpoznać w choreografii praktykę polityczną, która w swoim obrębie może eksplorować interakcje społeczne, a zarazem być konkretną krytyką ich obecnych instytucjonalizacji. Pamięć zbiorowa i indywidualne doświadczenie wspólnotowości znajdują się także w centrum projektu Sense-action Tomasza Ciesielskiego, umieszczonego przez autora w paradygmacie praktyki-jako-badania. Umożliwia mu on refleksję na temat własnej działalności artystycznej i naukowej w jej dydaktycznym aspekcie, który ujawnia się jednak dopiero po rozpoznaniu choreograficznego wspólistnienia obu porządków doświadczenia badacza - sztuki i nauki.

Problemowi nauczania poświęcony jest tekst Sebastiana Cortésa. Ten choreograf i pedagog opisuje w swym rozdziale zastosowanie strategii choreograficznych jako narzędzi w treningu aktorskim. Kontekst metodologiczny zbudowany na współczesnych naukach kognitywnych umożliwia autorowi konceptualne, a nie tylko praktyczne powiązanie praktyk tanecznych z dominującą w Europie tradycją tzw. metody Stanisławskiego. Ostatnie dwa teksty tomu stanowią jego otwarcie, dyskursywne i twórcze, na choreografię jako ożywione i subiektywne 
doświadczenie cielesne (ang. corporeal). Próbą takiego indywidualnego ujęcia jest praca Aleksandry Ścibor, w której autorka w poetycki sposób opowiada o własnym przeżyciu traumy i uwolnienia od niej dzięki praktykom choreograficznym. Wreszcie wypowiedzią, która jeszcze dalej odsuwa się od normatywnych strategii tworzenia wiedzy, jest cykl zdjęć Marty Ankiersztejn. Fotografka zbiera w nim i formatuje zdjęcia tak, by ukazywały działające w nich heterogeniczne sily. Mimo ich zapisu $\mathrm{w}$ formie obrazu generowana przez nie wibracja jest rozpoznawalna cieleśnie - jako „niewidzialny ruch zamrożony w kadrze”.

\section{Lektura}

Teksty zebrane w niniejszym tomie nie dają się ułożyć w jednorodną, linearną całość. Jak wskazujemy na początku tego rozdziału, interesuje nas wielopoziomowa i wieloaspektowa interakcja heterogenicznych czynników, która staje się możliwa dzięki obecności w każdej z zamieszczonych tu prac odpowiednich strategii choreograficznych. Są one zatem rozpoznawalne w działaniach artystycznych przytaczanych przez autorów, w przyjętych przez nich interdyscyplinarnych metodologiach i nieoczywistych relacjach, jakie pojawiają się pomiędzy kolejnymi rozdziałami. $Z$ tego powodu przyjęty przez nas układ tekstów ma jedynie charakter propozycji i, w pewnej optyce, odzwierciedla rizomatyczne myślenie, jakie towarzyszyło pracom nad tą publikacją.

Dziękujemy autorom tekstów zawartych w Strategiach choreograficznych za odwagę w przyjmowaniu niecodziennych strategii badawczych, odsłanianiu indywidualnych i często prywatnych doświadczeń twórczych, a także za zgodę na udział w tym projekcie. Jednocześnie potencjalnych Czytelników zachęcamy do przyjęcia takiej samej postawy podczas lektury tej książki.

\section{Bibliografia}

Bateson G. (1972), Steps to an Ecology of Mind, Chandler Publishing Co., San Francisco. Brackman A.C. (1980), A Delicate Arrangement: The Strange Case of Charles Darwin and Alfred Russel Wallace, Times Books, New York.

Brooks J.L. (1984), Just Before the Origin: Alfred Russel Wallace's Theory of Evolution, Columbia University Press, New York.

Cielątkowska Z.M. (2013), Maurice Merleau-Ponty - ucieleśnienie wzroku, ucieleśnienie ciała, [w:] S. Nieśpiałowska-Owczarek, K. Słoboda (red.), Przyjdźcie, pokażemy Wam, co robimy. O improwizacji tańca, Muzeum Sztuki w Łodzi, Łódź.

Gelder Tim van (1995), What Might Cognition Be, If Not Computation?, „Journal of Philosophy" t. 92, $\mathrm{nr} 7$.

Maruyama M. (1963), The second cybernetics: Deviation-amplifying mutual causal processes, „American Scientist” t. 51, nr 2. 
Mlodinow L. (2012), Nieświadomy mózg. Jak to, co dzieje się za progiem świadomości, wpływa na nasze życie, tłum. J. Szajkowska, Prószyński i S-ka, Poznań.

Smith C.H. (2004), Wallace's unfinished business: The "Other Man" in evolutionary theory, „Complexity”, t. 10. DOI:10.1002/cplx.20062

Wallace A.R. (1858), On the Tendency of Varieties to Depart Indefinetly from the Original Type, Linnaean Society Papers, London. Reprint: P. Appleman (red.), Darwin. Norton Critical Edition, New York 1970. 